\title{
12 \\ Uncanny rights and the ambiguity of state authority in the Gambier Islands
}

\author{
Alexander Mawyer
}

On Mangareva, in French Polynesia's Gambier Islands, the legitimacy and warrant of the state to regulate and oversee pearl cultivators in the exploitation of local marine resources is being contested. This chapter considers ra'ui, a traditional Mangarevan conception of governance in the regulation of common resources, to bring into focus a contemporary response to the modernising state and the actions of one branch of its executive, the Ministère de la Perle, which is tasked with administering the important business of cultured pearls. These contestations draw attention to contemporary ambiguities in the character and qualities of resource rights and labour, particularly those mediating the relationships of Mangarevans to the state of Polynésie Française that today claims them. Moreover, this chapter suggests that the discursive contestation of the state, and of its representation in the communicative actions of the agents of the pearl ministry, raises the possibility that contemporary Pacific political regimes are haunted by their predecessors, certainly including France but perhaps also prior governments that were absorbed and displaced by France after the nineteenth-century annexation of the Gambier. This chapter is thus in conversation with work elsewhere in the contemporary Pacific that has demonstrated the appropriateness of attention to problematic 
realisations of modernist state forms, and how historically embedded social orders and cultural institutions, including various legacies of earlier political regimes, interfere with and complicate the articulation of governance in a Pacific context. Attention to the murky and nebulous character of everyday economies of power in French Polynesia seems timely, given the complexity of state formations, erosions, revaluations and instaurations over the last two centuries and in the last decades as the various statutes chartering state formation begin to sediment over one another in an incommodious political topology.

Drawing on doctoral fieldwork conducted in the village of Rikitea in French Polynesia's Gambier Islands, this chapter considers the contemporary relevance of the traditional concept of ra'ui for making sense of attempts to control and restrict marine resources, domains and activities. Assessing the character of politics in French Polynesian everyday life continues to be challenging after years of intense interand intra-party conflicts and regular overhauls of the presidency and territorial assembly, as well as periodic statutory overhauls of the relationship with France - a period widely referred to as the Taui (Change). The first section proposes that attention to ra'ui as a local conception of authority can contribute to the visibility and intelligibility of contemporary Mangarevans' contestations of regional and national legislation and regulations bearing on pearl labours. The second section turns to a series of sign postings bearing on local debates about the regulation of pearl labour in which, in the political churn and froth of the region's last decade, the fact of the state can seem to be a primary site of political life. By fact of the state, I mean the way that the state itself seems to be the concrete and focal object of political contest. Visible in the discursive intervention of these signs, however, is a claim that the presence and potency of the state should not be taken at face value. The final section turns to the question of what the recent politically and socially fraught decade in French Polynesia reveals about the character of the state's claims on the labours and rights of persons in French Polynesia's outer islands. It considers how the contestation of the state, the practical negotiation of its reach and significance in everyday life, highlights the curious endurance of other cultural and social institutions, including traditional cultural values, understandings and the practical orientations to action that they make possible. 


\section{Unrestricting ra'ui}

Scepticism about the character and constitution of the state-form in French Polynesia seems particularly warranted in the context of the uncertain disestablishment of the rule of chiefs in French Polynesia's Gambier Islands after the 1857 death of Maputeoa, the last 'Akariki Nui (King) of Mangareva to unambiguously hold the ao (the sacred rule of the Gambier). Following Osorio ${ }^{1}$ and others ${ }^{2}$ who have demonstrated the interpretive purchase offered by attention to traditional conceptions of community and polity, authority and agency, I want to join the other chapters collected here in suggesting that the right of chiefs to declare ra'ui and to apply restrictions over marine resources provides a historically sensitive micropolitical context for examining the problematic condition of state power and the ambivalent relation of its subjects to its impositions. In post-chiefly Polynesia the (in)effectual state sometimes becomes visible in the materiality of discourse over statutory and practical control of mundane powers. This, I believe, brings to light a critical question in the contemporary Pacific. What has happened and is happening to traditional cultures of governance? In places where they are not directly evident have they been utterly erased by history's tides or do they remain operating beneath or outside of statutory purview, just out of sight? Do they haunt the islands' administration as a spectral presence?

On Mangareva, the answers to these questions may be found in contemporary discursive engagement with the state in the areas of labour and marine resource use rights. In these areas, historical notions of ra'ui as the chiefly authority to restrict use rights are culturally highly salient and are curiously suggested by local political discourse. By way of teasing out a sense of the relevance of this concept, it is worth noting that the pre-contact practice of ra'ui in the Gambier was comparable to similar practices elsewhere in Polynesia. The earliest

\footnotetext{
1 Osorio, J.K.K., 2002. Dismembering Lähui: A History of the Hawai'ian Nation to 1887. Honolulu: University of Hawai'i Press.

2 Kelly, J.D., 1997. 'Gaze and grasp: plantations, desires, indentured Indians, and the colonial law in Fiji'. In L. Manderson \& M. Jolly (eds), Sites of Desire, Economies of Pleasure: Sexualities in Asia and the Pacific. University of Chicago Press, pp. 72-98; Kaplan, M., 2004. 'Neither traditional nor foreign: dialogues of protest and agency in Fijian history'. In H. Jebens, T. Otto \& K. Heinz Kohl (eds), Cargo Cult and Culture Critique. Honolulu: University of Hawai'i Press, pp. 59-79; Kelly, J.D., 2005. 'Boycotts and coups, shanti and mana in Fiji'. Ethnohistory, 52(1): 13-27.
} 
published dictionary of the Mangarevan language, Tregear's Mangarevan Dictionary, which is based on even earlier missionary works, offers this definition:

$R a^{\prime} u i$ To keep off, to defend; to prohibit, to forbid (said of lands, waters, of things which one declares tapu).

$R a^{\prime} u i^{\prime} u i$ Plural of the action.

Rara'ui Plural of the subject.

Ra'uiranga The action of $r a^{\prime} u i{ }^{3}$

Thus, to early European observers on Mangareva, ra'ui appears to have been understood as something like a weakened and less significant version of tapu, a contingent feature of a more cosmic, divine authority to restrict and control everyday practices, as expressed in the mundane realm. Yet it seems worth noting that the invocation of ra'ui implies the possibility of its breach. Thus, Tregear:

Tara'ui To steal a prohibited thing: said of the first who steals.

Tara'uiga The action of tara'ui. ${ }^{4}$

On consideration, ra'ui does not appear to have been merely a cosmically efficacious power to be taken for granted, but a structural tension pointing to the contingencies of the everyday, to the play of power in a full matrix of social life, in effect one of the currencies of chiefly power.

Today ra'ui and tara'ui do not have currency in the spoken language of the Gambier. Indeed, informants claimed that they have not been invoked here since the time of the conversion of the islands to Catholicism in the 1830s, and certainly no later than the disestablishment of sacred chiefly rule in the decades after the death of Maputeoa. Yet, the contingencies of labour rights and marine resource use remain, and continue to be, a source of tension between prohibited labours and everyday use rights. Indeed, both the labour of Mangarevan individuals and families, their rights to the act(s) of their bodies and their use of marine spaces, and the material benefits thereof, appear to be in a sort of crisis that perhaps tells us something about the overall crisis of the state in French Polynesia's outer islands.

3 Tregear, E., 1899. Mangareva Dictionary of the Gambier Islands. Wellington: Government Printing Office.

4 Tregear, 1899. 
Here it is not the legal imbroglio resulting from the region's statutory decolonisation and the political chaos that has characterised its government, but something at once everyday and practical and yet hinged to the ineffably historical - something latent in the way that rights to labour with respect to the (un)common goods and resources of the sea mediate understandings of the social.

\section{The mad poster and perliculture's persistent crisis}

During my doctoral field research in anthropology in French Polynesia's Gambier Islands in 2002 and early 2003, a series of publicly posted signs revealed the presence of enduring ambiguities in the character of state authority. Notably, the intensity of the French state's regional presence in its nuclear testing regime did not lead me to anticipate any ambiguity in the fact of the state on the ground. These signs suggested that, over a century after the gradual disestablishment of sacred chiefs in the Gambier Islands following the establishment of a French Protectorate in 1881, and the absorption of the Gambier into an administrative district with historically evolving regulatory regimes over subsequent historical periods, Mangarevans still ask who has inherited the ao (the rule of the land and the sea) including the rights to restrict their use.

In the Gambier, as in the Tuamotu, attempts to govern and administer the business of culturing pearls and daily labours on pearl farms seem to offer an excellent point of contact between Mangarevans' intimate experiences and the state from the age of the chiefs to the present. ${ }^{5}$ In the current era, since the institution of the cultured pearl as the centre post of socioeconomic life in the Gambier in the 1970s and 1980s, economists, administrators and others have been charged with monitoring the market for so-called 'Tahitian' black pearls, bringing local labours into regional and global visibility. Even early on, such surveillance yielded disturbing indications regarding the stability

5 Rapaport, M., 1995. 'Pearl farming in the Tuamotus: atoll development and its consequences'. Pacific Studies, 18(3): 1-25. 
of the pricing and volume of pearl sales. ${ }^{6}$ For years, however, it was possible to ignore disquieting signs. This changed in February of 2001. A disastrous vente aux enchères, or scheduled auction of pearls on the international market, which was usually held once or twice annually, revealed a crise persistante and tendance inquiétante (persistent crisis and disquieting tendency) in the slowing growth, or actual decline, of the gem prices by lot. ${ }^{7}$

After years of loose oversight, the government's response was dramatic. Within months a Service de la Perliculture was implemented that was, shortly thereafter, restructured and promoted to a full Ministère de la Perle with sweeping powers to survey and regulate pearl culturing. What the agents of the new executive structure discovered as they began to take stock of the state of pearl culturing and labour over the following year was a discontinuity between the long-running official perspective and the facts of perliculture and labour in the Gambier. Apparently unrecognised by the government and ignored by the several syndicates that dominate the cultured black pearl market, the number of independent families and individual persons culturing pearls in the Gambier exploded in the 1990s. Administration agents expressed real shock in the discovery that the total number of fermes

6 As early as 1992, the Service de la Mer et de l'Aquaculture (SMA), which overlapped with and eventually replaced Etablissement pour la Valorisation de Activités Aquacoles et Maritimes (EVAAM) in the 1990s and preceded the Service de la Perliculture, reported a range of industry problems including the 'uncontrolled occupation of the lagoon', the absence of adequate legislation and a general 'lack of knowledge on the actual status of the industry'. To a large degree, the impossibility of monitoring the activities of producers was, at the time, seen to be cartographic - producing an inventory of pearl farming areas and subsequent monitoring was impossible, the service claimed, because of the 'non-availability of a homogeneous set of maps of the appropriate scale for the thirty-odd pearl farming areas: the existing topographic and hydrographic maps do not give comprehensive coverage and are not of much practical use (they do not, for instance, show the karena, or coral pinnacles, which pearl farmers use to attach their ropes)' (South Pacific Commission, 1992. Pearl Oyster Information Bulletin no. 4, February).

7 An administration report from the period offers further details. 'The 1998-2000 period saw an exceptional growth in the pearl industry, with a 75 per cent increase in the volume of exported pearl products, and a 38.7 per cent increase in the receipts generated by exports. This increase in exported volumes resulted in additional but less important (in terms of value) receipts. Indeed, the price of a gram of pearl has kept on falling for several years (XPF 2359/gram in 1998, XPF 1766/gram in 2000, XPF 1357/gram in 2001, and XPF 1326/gram in 2002). There was a reversal of situation in this sector in 2001, which resulted in a 28.4 per cent decrease in sales value abroad ( -8 per cent in volume). Sales of pearl products reached, that year, XPF 15 billion with difficulty (the same amount of sales was reached in 1998). The pearl industry sector stabilised in 2002 at the same level of sales for rough pearls, finely-worked pearls, and for other pearl products' (www.presidence.pf/index.php?94). 
(pearl farms) and, presumably, the quantity of gems entering the market far exceeded both official and unofficial estimates, to well over 100 pearl farms in 2002.

Most of these cultivators were out of compliance with the stringent statutes and regulations developed as the business of perliculture matured after the 1970s. After pearl prices on the international market plummeted in 2001, one of the officers of the governmental inquiry claimed to me that fewer than 10 per cent of all Gambier fermes perliers were in compliance with the various regulations governing their labour. Perhaps this should not have been surprising since there is ample room for circumventing dozens of regulations, including the amount of sea space occupied, the number of oysters in cultivation, the periods of their harvest, and techniques bearing on the size of the implant used to seed the oyster.

The actions taken by the administration and the Ministère de la Perle in response to this perceived crisis eventually led to a series of widely attended public meetings on Mangareva in late 2002. It was in the midst of these meetings that a series of sign postings pointed to the ways in which local economies of power, individual and collective actions and the understandings of rights and duties that underlie them are experienced outside of, or perpendicular to, common sense conceptions of the presence and authority of the state. The first of these meetings, in October, ended in what could only be described as a disaster for administration representatives. Intended to be a simple presentation of the administration's new regulations, executive orders and practical actions in service of re-regulating perliculture in the Gambier, the presentation was derailed by a series of deliberate moves to hold the discussion in Mangarevan, a language not shared by the administration's representatives. Moreover, the negotiation of the code shift into Mangarevan was followed by a topic shift to focus on what basis Mangarevans themselves would be entitled to address those assembled. These discursive moves drew attention to rifts in local understandings of 'us' and 'you'. Unable to speak, much less complete their presentations, the agents of the new pearl services left the island, cutting short their stay to report back to the administration under what I was told were emergency conditions. 
In the weeks following this first abortive meeting, details of the unrealised presentation began to circulate. A flyer made available at the town hall listed a series of new regulations governing membership in a lawful pearl cooperative, and requirements for compliance by all those who had already begun culturing pearls. Most significantly, the new rules sought to regulate pearl labour, requiring potential farmers to sit various courses and pass exams in order to qualify as licensed producers. They also determined how many lines and oysters a person could cultivate, in how much space at sea, and how concessions of sea space would be allocated. Implicit in all of these proposed changes was the fact that any redistribution of space, rights to cultivate, or modification of the rules for participation in the industry would be equivalent to a redistribution of potential wealth, most likely favouring well-established senior men on the island as opposed to youths or latecomers to the business of culturing pearls.

In their effects, such impositions are, as Trouillot observes, the manner in which modernist states become visible. ${ }^{8}$ Thus, in the new 'professional' requirements proposed in the meeting, we see what Trouillot identifies as the state's attempts to produce 'atomised individualised subjects molded and modelled for governance as part of an undifferentiated but specific "public"', along with their proposed 'realignment of the atomised subjectivities along collective lines within which individuals recognise themselves as the same' and 'production of both a language and a knowledge for governance and of theoretical and empirical tools that classify and regulate collectivities' as well as 'the production of boundaries and jurisdiction'. ${ }^{9}$ Outer islands in a not-quite-postcolonial situation are thus unsurprisingly excellent candidates to witness the aggressive and assertive state in action. What is surprising, however, is the way that such acts of governance also summon into renewed relevance competing traditional authorities and powers such as those of chiefs to ra'ui the use of land and sea, thus refiguring noncompliant persons as tara'ui (usurpers).

As the date of a second meeting approached, inside the island's small goods shops one could hear people asking each other the rhetorical question, 'Ah, the meeting is next week, right?' Groups of men standing

8 Troulliot, M-R., 2001. 'Anthropology of the state in an age of globalization'. Current Anthropology 42: 125-38.

9 Troulliot, 2001, p. 126. 
outside began to joke about what they would do with the producers' badges and identity cards that the regulations posted at the town hall proposed they carry along with an official state-mandated compass and knife as they went about their work. The compass requirement in particular was the object of innumerable jokes - since the notion that Mangarevans need an aid to know where they are in their own lagoon is locally laughable, its vast size notwithstanding. Men and women spoke openly about their sense that the administration had an alien perspective on Mangarevan maritime domains as dangerous spaces and did not understand that they were already domesticated according to a variety of local understandings, traditions and contemporary conventions.

Finally, in the last week before the meeting, the semiotic equivalent of a string of firecrackers was set off in the village due to the activity of an obviously impassioned, non-administration aligned, politically subtle and clearly irate sign poster. Over the course of a week any number of signs were posted at key spots around the village. Evidently there were supporters of the administration's point of view as well. As soon as a sign went up and was discovered by the counter-party, down it would come. The removal of the posting led to countermeasures such as posting the signs in remote corners of the island where, although fewer villagers would initially see them, news of the signs would necessarily filter back into the collective discussion. This led to putatively invisible adversaries cruising around or lying in wait at obscure junctions on the island's thoroughfares to post or remove one or another sign. The poster battle lasted the course of the week leading up to the second meeting and became part of a discursive debate with control of the sea space and its resources as the stake.

I was not able to collect the text of most of the signs, and there were many. For example, the first two I saw were on the road $i$ mua (the outward direction) from Rikitea where very few folks live. On the afternoon of 11 November, while out for a run, I spotted a series of flyers taped to the pillar of one of the meteorological service's weather stations, and recognised the oddity of their content. Since I did not have paper or pen on me I planned to return by bike but, by the time I did so only an hour later, they were missing, which was initially a complete mystery. Returning to the village I stopped in the first of the stores one comes to travelling in the $i$ roto (inward) direction back into town, and asked if anyone had seen these curious things. I was 
told that someone was putting them up, that no one knew who and that someone else was taking them down. The several folks who were in the store noted that signs had been posted on the doors of several of the stores in the morning, on telephone poles in front of the post office and school, and in several other spots in town, but that they were never there for long. This semiotic contest lasted over the next several days. The text of two signs is representative. The first is from the morning of 13 November, the day of the second meeting:

This lagoon is the heritage of the Mangarevan People. Recall the regime that has come to dispossess us of our lagoon, lands, culture. President, we are a vibrant and rich people, it is the Rikitea pearl that augments the market value of the Pearl of Quality.

Written in multicolour marker on the back of cardboard from a box, the fashioning of the sign seemed haphazard but aesthetically heartfelt. The morning after the meeting, a sign with the following text was posted on the pole that supports some meteorological equipment on the $i$ mua stretch of the road, where I had first seen one of the signs quite out of town:

The King conferred to the Catholic Church the protection and the development of these lands for the future of his Mangarevan people and to France the conservation of his lagoon and the protection of his resource 'la nacre' for her children.

Both signs present images of the conception of the historically inflected order of things, persons and their relation to forms of authority, of rights and the appropriate flow of rights from legitimate states. As is evident in these two signs, the local political order suffers from latent ambiguities. Is it the French Polynesian state or is it France that has the rule of the land and sea? Or did the Church, as a legacy of the mission period and the close attachments of the mission to the founding of the Mangarevan kingdom, acquire the authority of the previous political regime, a chiefly dynasty of 36 generations of 'Akariki, and thus legitimate rule of the land, leaving the sea as the express ward of France with legitimacy from the same source?

In the first sign, the new state of affairs is construed as a regime that threatens Mangarevans' legitimate rights to inherit the goods and benefits of their own lagoon. The question is thus one of sovereign authority. As the implied addressee of the sign, the president of French Polynesia certifies this. He is the holder of the ao (the rule) 
of the land. And, accordingly, since the then long-serving President Gaston Flosse is Mangarevan, he might be expected to be particularly sentimental about and supportive of Mangarevan rights to choose when and how to use and restrict the resources of their lagoon. The second sign implies an entirely different descent of rights and an entirely distinct construction of Mangarevan persons. In this case, the implied addressee is the French state, the national mother, who has the obligation to protect her children from each other; i.e. to protect Mangarevans in the outer islands from the manipulation of the Tahitian majority operating from the territorial centre. In this case, Mangarevans appear as wards of the French nation-state, directly inherited from the last traditionally authorised ruler of the island, Maputeoa, before his death.

The discursive materiality of the French Polynesian state's engagements here in its so-called outer islands thus suggests that the crisis of the state finds expression in the relationship between efficacious historical actors, taken to be chief players, as it were, in the drama of the social, the structures of social order through which their authority and legitimacy is derived, and the events in which authority is expressed, negotiated, resisted and instituted a la Sahlins. ${ }^{10}$ But, a century after the gradual disestablishment of sacred chiefs in the Gambier, it is unclear who has inherited the sacred power of the chiefs of yore. Who, or what, currently holds rights of sacred authority in this community is clearly a site of latent ambiguity, as is the relation of rights and obligations that pertains on the ground between Mangarevans and the state(s) that claims them as citizens. In the contemporary Gambier, such questions are of paramount importance, particularly as they bear on the potentially lucrative exploitation of marine resources and space, further contextualised in the Gambier because of the notorious intensity of the hierarchical social structure before regular contact with Western cultures, ${ }^{11}$ and for the equal intensity of processes of Westernisation and the disestablishment of chiefly power. ${ }^{12}$ When certain forms of state-sponsored agentive authority

10 Sahlins, M.D., 1985. Historical Metaphors and Mythical Realities: Structure in the Early History of the Sandwich Islands Kingdom. Association for the Study of Anthropology in Oceania, special publication 1. Ann Arbor: University of Michigan Press.

11 Sahlins, M.D., 1958. Social Stratification in Polynesia. Seattle: University of Washington Press.

12 Buck, P.H., 1938. Ethnology of Mangareva. Bulletin no. 157. Honolulu: Bernice P. Bishop Museum. 
attempt to assert themselves and legitimate their authority over rights to spatial practices and everyday labours in the Gambier, they can be challenged by other sorts of historically embedded notions of legitimate authority. The result appears to be a sort of spectral conflict, as otherwise ineffable historically superseded political regimes, here made temporarily discursively visible, return to discursive relevance and challenge the current state's claims to legitimate authority here in the region's 'outer islands'.

\section{Uncanny rights, prohibited labours}

I think we are right to ask whether attention to states' micropolitical practices has been too often displaced in ethnographic assimilations of the Pacific and perhaps especially Eastern Polynesia, not because ethnographers were uninterested in power and politics but because state effects did not fit the representational models of certain durable and consistent understandings to which the diverse facts of regional cultures had been reduced. Consider ethnographers' longenduring fondness for traditional conceptions of power in Polynesia. An abstract otherworldly force given concrete substance in the term mana on one hand ${ }^{13}$ and reified in towering hierarchical structures on the other, ${ }^{14}$ power has been taken to be a key hinge in the unfolding historical engagement of Western social science and Pacific cultures. This vast literature, however, is dominated by a relatively small set of persuasive if potent mot essentiaux ${ }^{15}$ and idées maîtresses ${ }^{16}$ (key words and determining ideas) which belie the complexity and variety in the everyday economies of power across diverse historical and sociopolitical contexts. Specifically, the closely associated ideas

13 Keesing, R.M., 1984. 'Rethinking mana'. Journal of Anthropological Research 40(1): 137-56; Shore, B., 1989. 'Mana and Tapu: a new synthesis'. In A. Howard \& R. Borofsky (eds), Developments in Polynesian Ethnology. Honolulu: University of Hawai'i Press, pp. 137-74; Tomlinson, M., 2006. 'Retheorizing mana: Bible translation and discourse of loss in Fiji'. Oceania, 76(2): 173-85.

14 Sahlins, 1958; Douglas, B., 1979. 'Rank, power, authority: a reassessment of traditional leadership in South Pacific societies'. Journal of Pacific History 14: 2-27; Valeri, V., 1985. Kingship and Sacrifice: Ritual and Society in Ancient Hawai'i. Paula Wissing (trans). University of Chicago Press.

15 Baré, J-F., 1987. Tahiti, Les Temps et Les Pouvoirs: Pour Une Anthropologie Historique du Tahiti Post-Européen. Paris: Éditions de l'Orstom.

16 Mauss, M., 1973 (1923-24). Essai sur le don: Forme et raison de l'échange dans les societies archä̈ques In Sociologie et Anthropologie. PUF, Collection Quadrige, pp. 149-279. 
of mana, tapu and chiefliness have been the standard currency of the discursive fashioning of Polynesian persons and their structures of practice and experience.

In the deliberation of the longue durée $e^{17}$ played out between competing representations of agency and authority, structure and event, legitimacy and contestation, ${ }^{18}$ as realised through these terms, one wonders whether the ethnographic literature on Polynesia has a disquieting tendency to interpret the operations of power too exclusively in terms of structurally amplified authority, the mana inhering in vertically assembled individual persons and traditional institutions, and the potent warrants thereby produced or enacted. Following work in Hawai'ian and Pacific studies, it seems clear that scholars have systematically overlooked the importance of other traditional conceptions of mundane powers, the everyday micropolitical clashes of successive legal frameworks and administrative regimes as historically emergent governing states grapple with the legacies of their predecessors and institute the constitutional developments that will bedevil their successors. ${ }^{19}$

Given the tendency of Pacific anthropologists to eschew the mundane in favour of the cosmic, the ambivalent comportments of individuals in favour of vertically structured institutions, we might well ask with Keesing $^{20}$ and Jolly ${ }^{21}$ if ethnographers have too often gone native in a curious and at times fantastic archipelago of ideas, too removed from what are ultimately the intimate experiences of real people. ${ }^{22}$ Attention to everyday discursive contestations between states and individuals engaged in daily labours within common spaces appears to be a timely and well warranted turn in contemporary Pacific and Polynesian studies. With reference to the contested character of the state made

17 Thomas, N., 1989. 'The force of ethnology: origins and significance of the Melanesia/ Polynesia division'. Current Anthropology 30(1): 27-34; Thomas, N., 1997. In Oceania. Durham: Duke University Press.

18 Dening, G., 1980. Islands and Beaches: Discourse on a Silent Land: Marquesas 1774-1880. Chicago: The Dorsey Press; Sahlins, 1985.

19 Kame'eleihiwa, L., 1992. Native Lands and Foreign Desires, Ko Hawai'i Aina a me Na Koi $P u^{\prime}$ umake a ka Po'e Haole. Honolulu: Bishop Museum Press.

20 Keesing, R.M., 1985. 'Conventional metaphors and anthropological metaphysics: the problematic of cultural translation'. Journal of Anthropological Research 41: 201-17.

21 Jolly, M., 2007. 'Imagining Oceania: indigenous and foreign representations of a sea of islands'. The Contemporary Pacific, 19(2): 508-45.

22 Shore, B., 2005. 'Reading Samoans through Tahitians'. Ethos 33(4): 487-92. 
discursively material, as in signposting practices, among any number of analogous quotidian engagements between local persons and the otherwise all too translucent tentacles of the ghostly leviathan of the states that attempt to govern them, I am encouraged to think that Pacific scholars can identify terms and forms of everyday power that clarify Pacific lives in ways that reference to standard understandings of mana, for instance, may not. What attention to the concept of $r a^{\prime} u i$ as it contextualises political discourse bearing on marine resources may suggest is that the very action of the state, visible also in its effects, is producing uncanny feelings and sentiments, ${ }^{23}$ disconcerting senses of familiar labours and common sense rights as strange here raising into visibility the spectre of the past and the previous rule of chiefs.

Like many manual labours, working on a pearl farm is a daily grind involving repetitive tasks centered on the health of the developing oysters, the security of lines and nets, and the maintenance of tools and vehicles. Periods of intense excitement are short-lived, few and far between. They punctuate days that consist of motoring out into the lagoon and free diving for a few dozen nets that must be taken back to the farmhouse. The farmhouse is typically a platform resting a few metres above sea level some distance from shore on concrete pillars poured in old gas barrels and put in place by producers who have essentially 'staked a claim' to a certain seaspace, either in conjunction with governmental authorisation (a concession to a domain), or according to purely local understandings of appropriateness of use reckoned through attachment of the incipient producers to lands recognised as their own kaiga (property), or nuku (maternal places).

The communicative assemblages that are latent in public meetings, sign postings and the equally potent discursive engagements latent in sign-removal, offer an example of concrete points of articulation between the contemporary French Polynesian state and its supposed subjects, as they make such everyday manual labours appear far from ordinary. The way that these signs summon ambiguously layered historical mentalities and competing understandings of the implications of the past for the present points to the incomplete

23 Artexaga, B., 2003. 'Maddening states'. Annual Review of Anthropology 32: 393-410; Throop, J., 2005. 'Hypocognition, a "sense of the uncanny", and the anthropology of ambiguity: reflections on Robert I. Levy's contribution to theories of experience in anthropology'. Ethos 33(4): 499-511. 
realisation of what is, after all, only the latest French Polynesian state, operating under a new statutory charter of autonomy as a Pays d'Outre Mer Territoire d'Outre Mer since 2004 with respect to continuing colonial France. They point to the uncanny presence of the shadows of states past, and the obligations and rights of its citizens in the Gambier. Here, such shadow states include the Territoire d'Outre Mer, the Etablissments Francaise d'Oceanie, the spectral protectorate, the short-lived statutory Kingdom of Mangareva, the also brief instauration of the Catholic Mission and, ultimately and originally, the enduring ao of traditional chiefs, the 'Akariki and Tongo'iti, before their entanglement with Western governmental regimes. These signs are best seen as short, historically sensitive commentaries on state rights of restriction. In these postings over time it becomes clear that the traditionally legitimate authority to regulate and restrict everyday labours and common resources in French Polynesia, once understood through the lens of $r a^{\prime} u i$, is now coexistent and yielding contemporary interference effects with successive projects of state(s) modernities.

These signs inherit or atavistically recapitulate past discursive contestation over legitimate marine rights and labours, $r a^{\prime} u i$ and their illegitimate counterparts, tara'ui. My ongoing investigation of the territorial archives in Papeete suggests that regulatory regimes bearing on pearl extraction and labour, and the discursive contest about them, were a central feature of the governance of these islands from the arrival of European ships bearing pearl divers in the early nineteenth century, often from elsewhere in Polynesia, into the protectorate period at the time of the demise of the Mangarevan kingdom in the late nineteenth century, and lasting until the Second World War. Hence, thinking about Osorio's work in Hawai'i, ${ }^{24}$ I cannot help but speculate that the inability of the traditional chiefs, the Gambier's 'Akariki and Togo'iti, to control labour in and the resources extracted from marine spaces, played a role in the instauration of the mission and its governance power, ${ }^{25}$ the eventual formation of the Mangarevan kingdom and, on its collapse, the subsequent and evidently complicated implementation of the protectorate and acceptance of French colonial rule over several decades. ${ }^{26}$ Official and unofficial letters, orders, reports, notes written in the margins of accounting documents of the town hall, minutes of

24 Osorio, 2002.

25 In the Gambier, the mission was regularly accused of having usurped the rule of the islands.

26 Vallaux, F., 1994. Mangareva et les Gambier. Tahiti: Etablissement Territorial D'Achats Groupes. 
meetings and reports of the Mangarevan Grand Council between 1886 and $1937^{27}$ show that requests for dispensations from a putatively 'central state' were virtually an annual affair, and that the independent action, tara'ui, of local and exterior persons in the absence of state authorisation was common in the exploitation of the Gambier's marine resources, particularly the lagoon's pearl oysters. Over the subsequent 150 years, marine resources remained a constant site of discursively constructed regimes of labour and restriction, and through them points of contact and friction between more or less efficacious state power and daily life.

Current state attempts to effectually govern pearl labour and marine resources, including new legislation and administrative discourse and action, may suggest to Mangarevans who are engaged in routine work on their pearl farms that they are engaged in tara'uiga, the usurpation of the legitimate restriction of a resource. As these signs suggest, this could literally be the case because the descent of the rights to ra'ui these resources is ambiguous. The result is that today, some Mangarevans are working to articulate an understanding of themselves as entitled and legitimate users and owners of these marine spaces and their product, what I identify as a set of uncanny rights. In the everyday fact of their labour, despite state attempts to prohibit it, the local rejection of the state's attempt to deny the rights to marine resource use, or labour activities, Mangarevans can be reminded that the authority to ra'ui various marine spaces has somehow not fallen into the hands of the current state that claims it. Again, this raises the question where has the right to ra'ui gone? Who holds it, the ao, of land and seascapes in the Gambier? ${ }^{28}$

27 Such requests are specifically notable in deliberation records from the years 1886, 1900, 1901, 1902, 1907, 1910 and 1937 (non-indexed manuscripts in the Territorial Archives, Papeete). 28 I want to thank Tamatoa Bambridge for urging me to work on this piece and for incisive suggestions. I also owe an aloha imbued thanks to Jeff Martin for his insights and generous guidance in reading in the anthropology of the state, and to Gary Mawyer and several anonymous reviewers for comments on an early draft. Thanks are also due to Bruno Schmidt, Yves Scanzi, Teri'i Seaman and many others in the punui of Rikitea and Papeete for gifts of friendship, time and insight into the politics of pearls. I want to particularly thank Monika Richeton, Rikitea's mayor, for her generous welcome and numerous supports, and for inviting me to be present at a number of formal events of governance during my time on Mangareva. The doctoral field research on which this chapter is based was conducted with the support of the US Department of Education Fulbright-Hays Program and the Wenner-Gren Foundation. 
This text is taken from The Rahui: Legal pluralism in Polynesian traditional management of resources and territories, edited by Tamatoa Bambridge, published 2016 by ANU Press, The Australian National University, Canberra, Australia. 